Radiochimica Acta 41, 191- 198 (1987)

c R. Oldenbourg Verlag, München 1987 - 0033-8230/87 $83.00+0.00$

\title{
The Impact of the Chernobyl Accident on a River/Groundwater Aquifer
}

\author{
By URSULA WABER, HANS R. VON GUNTEN* and URS KRÄHENBÜHL, Laboratorium für Radiochemie, \\ Universität Bern, CH-3000 Bern 9, Switzerland \\ * and Eidgenössisches Institut für Reaktorforschung, $\mathrm{CH}-5303$ Würenlingen, Switzerland
}

(Received December 17, 1986; revised January 15, 1987)

Radionuclides / River /Ground water / Particles / Chernobyl

\begin{abstract}
The radionuclides ${ }^{99} \mathrm{~m} \mathrm{Tc},{ }^{103} \mathrm{Ru},{ }^{131} \mathrm{I},{ }^{132} \mathrm{Te},{ }^{134} \mathrm{Cs}$ and ${ }^{137} \mathrm{Cs}$, resulting from fallout from the damaged nuclear power plant at Chernobyl (USSR) were measured several times between May $2^{\text {nd }}$ and $20^{\text {th }}, 1986$, in the River Glatt (Zürich, Switzerland) and in the adjacent shallow ground water stream. Samples from the river and from different groundwater wells were filtered $(0.45$, $0.20,0.05 \mu \mathrm{m})$. The resulting water and the filters were assayed by $\gamma$-ray spectroscopy. For all these nuclides the main radioactivity $(>75 \%)$ of the river water was found in the water passing the $0.05 \mu \mathrm{m}$-filter. The fraction $>0.45 \mu \mathrm{m}$ contained the main particulate activity. Upon infiltration of river water into the groundwater stream iodine, ruthenium and tellurium are not, or only slightly sorbed, probably due to the formation of anionic or neutral species, whereas cesium is completely retained by the sediments. Particulate $(>0.05 \mu \mathrm{m})$ infiltration from the river into the groundwater is a negligible process.
\end{abstract}

\section{Introduction}

About $80 \%$ of the drinking water supply of Switzerland is extracted from shallow quarternary aquifers. The ground water of these glacio-fluvial deposits is recharged to a large extent by infiltrating surface waters, e.g. rivers and lakes. The quality of the groundwater is, therefore, primarily dependent on the quality of the respective surface waters [1], and only secondarily influenced by the nature of the aquifer, the mean residance time, by water infiltrating from the surface and by biological processes.

As a result of increasing drinking water consumption it may become necessary in the future to reclaim the groundwater closer to the banks of rivers and lakes. This would reduce the filter and purification efficiency of the aquifer sediments. The process of industrialization and other human activities have also led to a rising pollution of the environment which may deteriorate the quality of the ground and drinking water. In addition, pollution may be accelerated by chemical and nuclear spills, a fact that was dramatically demonstrated during the recent series of large chemical and nuclear accidents which had unexpectedly big impacts on man and the environment. Chemical and radioactive pollutants may not only endanger man, animals and plants, but also delicate microorganisms which regulate important soil and groundwater properties.

Unfortunately not much is known about the processes that govern the infiltration and migration of pollution into the heterogeneous glacio-fluvial deposits which cover large parts of Switzerland and of the peri-alpine countries Whereas a few publications deal with the infiltration of dissolved pollutants $[1-8]$ from rivers into groundwater aquifers, nothing is known, to our knowledge, about the behaviour of particulate or colloidal pollution in this process. The literature concerning the transport of pollutants by particulates and colloids in rivers is more abundant [9-12]; however, the majority of the publications deals only with size fractions $>0.45 \mu \mathrm{m}$. Furthermore, little information exists about the fate and distribution of atmospheric fallout between particles and colloids of aquatic systems.

The accident at the nuclear power plant at Chernobyl (USSR) on April 26, 1986, resulting in a release of large quantities of radionuclides into the atmosphere and their distribution over most of Europe, offered, among others, the possibility to investigate the fate of atmospheric pollution after entering aquatic systems. It also allowed the investigation of the infiltration and migration behaviour of radionuclides (in dissolved or particulate form) from the River Glatt (Zürich, Switzerland) into the adjacent shallow groundwater which is extensively used as a drinking water source in the agglomeration of Zürich. Thus, the accident at Chernobyl has contributed to a better understanding of the behaviour of radionuclides in natural aquatic systems.

\section{Experimental}

\subsection{Field site}

A well equipped test field was available for these investigations [13]. It is located near Glattfelden (Zürich, Switzerland) in the lower Glatt Valley (Fig. 1). Here, the polluted River Glatt infiltrates continually into the adjacent groundwater system. This aquifer consists of glaciofluvial sediments with stones, gravel, sand, silt and clays as the main components. Mineralogically quartz and calcite contribute to more than $60 \%$ of the aquifer, minor components are feldspars and dolomite and the claysize fraction (mostly chlorites and illites) [13]. The test field is equipped with a number of wells at different distances from the river along an estimated flow line of the groundwater (Fig. 1). The wells are lined with PVC-tubes and screened at the depth of the mean groundwater level. For this work the wells no. 1, no. 3 and no. 4 (distance from the river $2.5,4.5$ and 5.0 meters, respectively) were used to observe the infiltration of the radionuclides. Previous to this study the flow velocity of the groundwater was measured to be 2.5 meters per day [14] but unfortunately the local direction of the groundwater flow 


\section{RIVER GLATT}

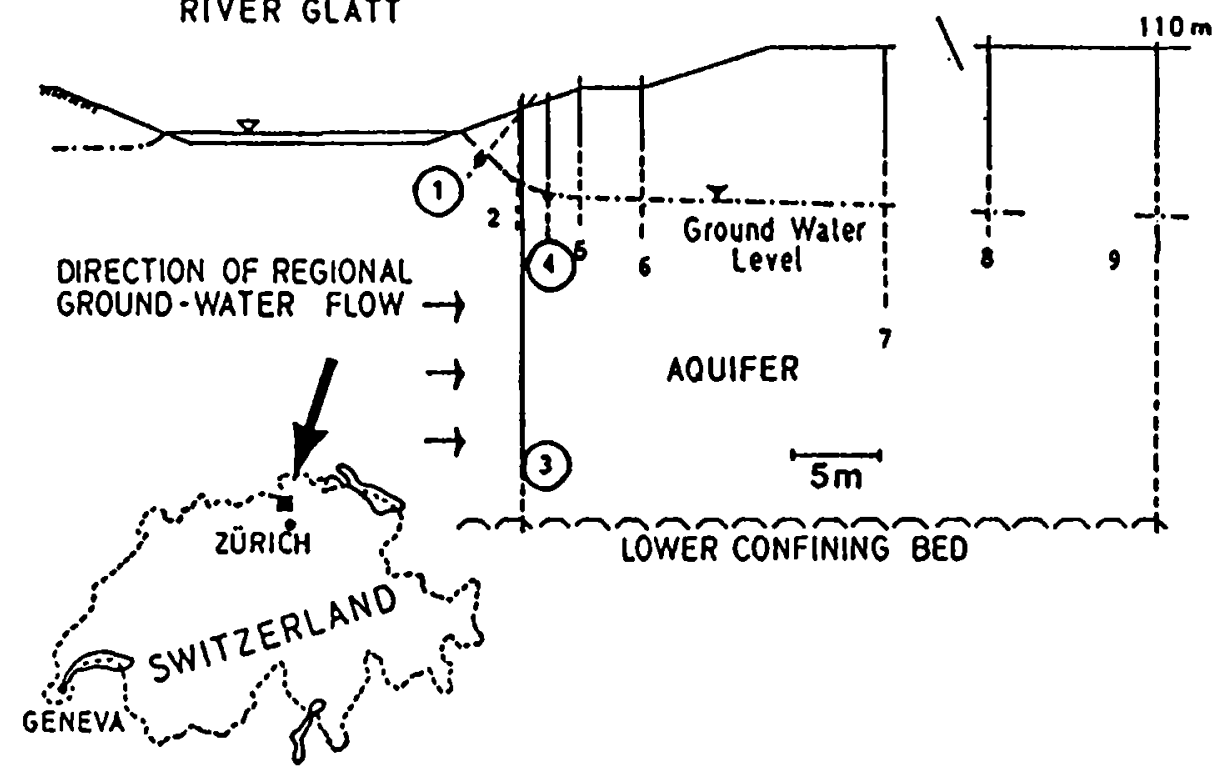

Fig. 1. Situation and cross section through the test field, showing the infiltrating river and the sampling wells along an estimated flow line of the groundwater. Wells no. 1 , no. 3 and no. 4 were used. The broken lines indicate the screened section of the wells. According to [13].

is not known exactly. The water in well no. 1 is probably about one day old river water, while that in well no. 4 infiltrated from the river about two days before. The water of well no. 3 was used as a reference of uncontaminated deep groundwater.

\subsection{Sampling and sample treatment}

River water samples were collected on May $2^{\text {nd }}, 4^{\text {th }}, 5^{\text {th }}$, $12^{\text {th }}$ and $20^{\text {th }}$ by submerging 10 -liter plastic bottles close to the river bank. Groundwater samples were taken on May $5^{\text {th }}$ and $13^{\text {th }}$, only. Due to limitations in the counting capacity it was not possible to handle more samples. The groundwater samples were collected using submersible plastic pumps (COMET, FRG), teflon tubes and polyethylene bottles. Before sampling, the wells and the equipment were flushed with several liters of groundwater in order to remove possible contamination. The ground was covered with plastic sheets to further reduce the risk of contamination by radioactive fallout. A low pumping rate $\left(0.5-1\right.$ liter $\left.\mathrm{min}^{-1}\right)$ allowed to collect the samples without disturbing the natural groundwater flow. Ten liters of water were taken from each site and transported to our laboratory where they were filtered either through folded filters (Schleicher \& Schüll) or membrane filters (Sartorius, dia $100 \mathrm{~mm}$ ) with pore size $0.45 \mu \mathrm{m}$ (cellulose acetate), $0.20 \mu \mathrm{m}$ and $0.05 \mu \mathrm{m}$ (cellulose nitrate), (Tables 1 and 2). After filtration the water samples were transferred into five 2-liter polyethylene bottles for the $\boldsymbol{\gamma}$-ray measurement. The filters were rolled and transferred into small glass tubes for the assay of radioactivity. In an additional experiment the chemical speciation of ${ }^{131} \mathrm{I}$ was investigated in the river water of
May $5^{\text {th }}, 1986$. To five liters of $0.05 \mu \mathrm{m}$-filtered water iodide and iodate carriers and an appropriate amount of lead nitrate was added to precipitate lead iodate. The ${ }^{131}$ I was then assayed by $\gamma$-ray spectroscopy of both, the precipitate and the filtrate, thus indicating the partition of ${ }^{131} \mathrm{I}$ between iodate and iodide in the $<0.05 \mu \mathrm{m}$ filtered river water.

\subsection{Activity measurements}

Ten liters of filtered water in five 2-liter polyethylene bottles were arranged around and on top of a large $\mathrm{Ge}(\mathrm{Li})$ detector. This was the most effective counting arrangement for the large amount of water. The glass tubes containing the rolled filters (see above) were counted in a $\mathrm{Ge}(\mathrm{Li})$ well detector. Counting times between 5 and 30 hours were necessary to obtain sufficiently small counting errors. The background was measured several times during the experiments in order to check for possible contamination by radioactive fallout which might have entered the counting room. The following nuclides and energies were measured: ${ }^{99 \mathrm{~m}} \mathrm{Tc}: 140.5 \mathrm{keV} ;{ }^{103} \mathrm{Ru}: 497.1 \mathrm{keV} ;{ }^{131} \mathrm{I}$ : $364.5 \mathrm{keV} ;{ }^{132} \mathrm{Te}: 228.2 \mathrm{keV} ;{ }^{134} \mathrm{Cs}: 604.7 \mathrm{keV}$ and ${ }^{137} \mathrm{Cs}$ : $661.6 \mathrm{keV}$. Detection limits were calculated with a modified version of a method of CURRIE [15], using data of the respective spectra or of one from the reference groundwater of well no. 3. All activities were normalized to April $30^{\text {th }}, 1986,12^{\circ 0} \mathrm{~h}$. The detectors were calibrated for the different sample geometries with standard radionuclides obtained from Amersham (GB) and the Swiss Reactor Institute (EIR). Only a relative standard was available for ${ }^{99} \mathrm{~m} \mathrm{Tc}$, making possible a comparison of activities in the water and on the filters. Errors of the 
Table 1. Activity $[\mathrm{Bq} / 1]$ in the river water, normalized to April 30th, 1986, $12^{\circ 0}$

\begin{tabular}{|c|c|c|c|c|c|c|c|}
\hline \multirow{2}{*}{$\begin{array}{c}\text { Date } \\
\text { May } 1986\end{array}$} & \multirow[t]{2}{*}{ Filters } & \multicolumn{6}{|c|}{ Measured nuclides } \\
\hline & & ${ }^{131} I$ & ${ }^{132} \mathrm{Te}$ & ${ }^{1 \bullet 3} \mathrm{Ru}$ & ${ }^{134} \mathrm{Cs}$ & ${ }^{137} \mathrm{Cs}$ & $99 \mathrm{~m}_{\mathrm{Tc}}$ \\
\hline \multicolumn{8}{|c|}{ a) particles on filters } \\
\hline $\begin{array}{l}2 \\
4 \\
5\end{array}$ & $\begin{array}{l}\text { folded filter } \\
\text { folded filter } \\
\text { folded filter }\end{array}$ & $\begin{array}{l}2.16 \\
0.85 \\
0.81\end{array}$ & $\begin{array}{l}3.06 \\
0.99 \\
0.92\end{array}$ & $\begin{array}{l}0.66 \\
0.22 \\
0.39\end{array}$ & $\begin{array}{l}0.16 \\
0.04 \\
0.10\end{array}$ & $\begin{array}{l}0.24 \\
0.08 \\
0.10\end{array}$ & \multirow{4}{*}{ n.d. ${ }^{2}$} \\
\hline $\begin{array}{l}5 \\
5 \\
5\end{array}$ & $\begin{array}{l}>0.45 \mu \mathrm{m} \\
0.20-0.45 \mu \mathrm{m} \\
0.05-0.20 \mu \mathrm{m}\end{array}$ & $\begin{array}{l}0.20 \\
0.04 \\
0.03\end{array}$ & $\begin{array}{l}1.14 \\
0.15 \\
0.10\end{array}$ & $\begin{array}{l}0.23 \\
0.05 \\
0.02\end{array}$ & $\begin{array}{l}0.06 \\
0.01 \\
\text { n.d. } 2\end{array}$ & $\begin{array}{l}0.08 \\
0.01 \\
0.01\end{array}$ & \\
\hline $\begin{array}{l}12 \\
12 \\
12\end{array}$ & $\begin{array}{l}>0.45 \mu \mathrm{m} \\
0.20-0.45 \mu \mathrm{m} \\
0.05-0.20 \mu \mathrm{m}\end{array}$ & $\begin{array}{l}0.42 \\
0.26 \\
0.17\end{array}$ & $\begin{array}{l}1.06 \\
0.60 \\
\text { n.d. } 2\end{array}$ & $\begin{array}{l}0.14 \\
0.16 \\
0.04\end{array}$ & $\begin{array}{l}\text { n.d. } 2 \\
\text { n.d. } 2 \\
\text { n.d. } 2\end{array}$ & $\begin{array}{l}0.09 \\
0.05 \\
0.06\end{array}$ & \\
\hline $\begin{array}{l}20 \\
20 \\
20\end{array}$ & $\begin{array}{l}>0.45 \mu \mathrm{m} \\
0.20-0.45 \mu \mathrm{m} \\
0.05-0.20 \mu \mathrm{m}\end{array}$ & $\begin{array}{l}0.25 \\
0.04 \\
0.03\end{array}$ & $\begin{array}{l}<1.74 \\
<0.52 \\
\quad \text { n.d. }\end{array}$ & $\begin{array}{l}0.06 \\
0.02 \\
0.01\end{array}$ & $\begin{array}{c}0.04 \\
<0.001 \\
\text { n.d. } 2\end{array}$ & $\begin{array}{l}0.04 \\
0.01 \\
0.01\end{array}$ & \\
\hline \multicolumn{8}{|c|}{ b) filtrated water } \\
\hline $\begin{array}{l}2 \\
4 \\
5\end{array}$ & $\begin{array}{l}\text { folded filter } \\
\text { folded filter } \\
0.05 \mu \mathrm{m} \text { filtrated }\end{array}$ & $\begin{array}{r}22.19 \\
6.96 \\
8.12\end{array}$ & $\begin{array}{r}20.33 \\
10.87 \\
8.98\end{array}$ & $\begin{array}{l}1.89 \\
1.08 \\
0.89\end{array}$ & $\begin{array}{r}0.87 \\
0.39 \\
<0.06\end{array}$ & $\begin{array}{l}1.17 \\
0.76 \\
0.62\end{array}$ & \multirow{3}{*}{ n.d. 2} \\
\hline $\begin{array}{l}12 \\
12\end{array}$ & $\begin{array}{l}0.45 \mu \mathrm{m} \text { filtrated } \\
0.05 \mu \mathrm{m} \text { filtrated }\end{array}$ & $\begin{array}{r}10.65 \\
1.51\end{array}$ & $\begin{array}{r}6.99 \\
<5.63\end{array}$ & $\begin{array}{l}1.57 \\
0.99\end{array}$ & $\begin{array}{l}0.69 \\
1.23\end{array}$ & $\begin{array}{l}1.09 \\
\text { n.d. } 2\end{array}$ & \\
\hline $\begin{array}{l}20 \\
20\end{array}$ & $\begin{array}{l}0.45 \mu \mathrm{m} \text { filtrated } \\
0.05 \mu \mathrm{m} \text { filtrated }\end{array}$ & $\begin{array}{l}6.35 \\
5.15\end{array}$ & $\begin{array}{l}\text { n.d. } 2 \\
\text { n.d. } 2\end{array}$ & $\begin{array}{l}1.10 \\
0.92\end{array}$ & $\begin{array}{l}\text { n.d. } 2 \\
\text { n.d. } 2\end{array}$ & $\begin{array}{l}0.41 \\
0.43\end{array}$ & \\
\hline
\end{tabular}

1 counts per second and liter

2 n.d.: not detected, limit unknown.

Table 2. Activity $[\mathrm{Bq} / 1]$ in the ground water, normalized to April $30 \mathrm{th}, 1986,12^{\mathrm{oO}}$

\begin{tabular}{llllllll}
\hline $\begin{array}{c}\text { Date } \\
\text { May } 1986\end{array}$ & Filters & \multicolumn{5}{c}{ Measured nuclides } \\
\cline { 2 - 7 } & & ${ }^{131} \mathrm{I}$ & ${ }^{132} \mathrm{Te}$ & ${ }^{103} \mathrm{Ru}$ & ${ }^{134} \mathrm{Cs}$ & ${ }^{137} \mathrm{Cs}$ & ${ }^{99 \mathrm{~m}^{3} \mathrm{Tc}}$ \\
\hline
\end{tabular}

a) particles on filters

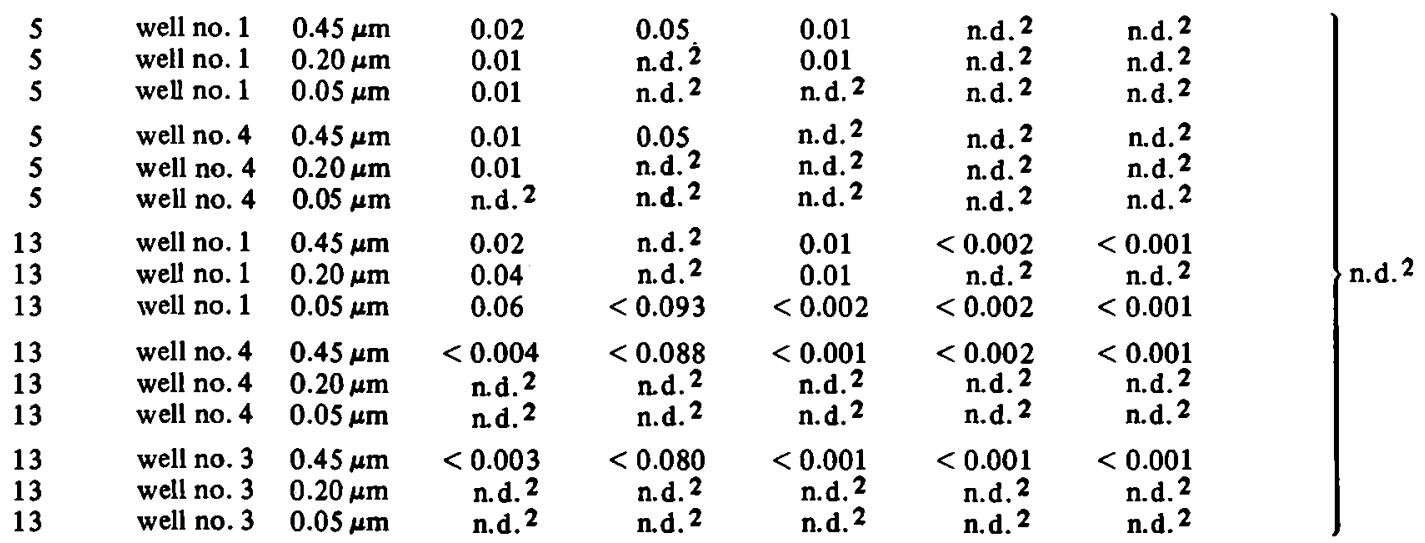

b) filtrated water

\begin{tabular}{|c|c|c|c|c|c|c|c|c|}
\hline $\begin{array}{l}5 \\
5\end{array}$ & $\begin{array}{l}\text { well no. } 1 \\
\text { well no. } 1\end{array}$ & $\begin{array}{l}0.45 \mu \mathrm{m} \\
0.05 \mu \mathrm{m}\end{array}$ & $\begin{array}{l}6.31 \\
7.38\end{array}$ & $\begin{array}{c}2.92 \\
<1.354\end{array}$ & $\begin{array}{l}0.21 \\
0.80\end{array}$ & $\begin{array}{l}\text { n.d. } 2 \\
\text { n.d. } 2\end{array}$ & $\begin{array}{l}\text { n.d. } 2 \\
\text { n.d. } 2\end{array}$ & $\begin{array}{l}\text { n.d. } 2 \\
\text { n.d. } 2\end{array}$ \\
\hline $\begin{array}{l}5 \\
5\end{array}$ & $\begin{array}{l}\text { well no. } 4 \\
\text { well no. } 4\end{array}$ & $\begin{array}{l}0.45 \mu \mathrm{m} \\
0.05 \mu \mathrm{m}\end{array}$ & $\begin{array}{l}11.80 \\
12.81\end{array}$ & $\begin{aligned} & 3.30 \\
< & 1.726\end{aligned}$ & $\begin{array}{l}0.89 \\
0.90\end{array}$ & $\begin{array}{l}\text { n.d. } 2 \\
\text { n.d. } 2\end{array}$ & $<\begin{aligned} & 0.174^{3} \\
&<0.045\end{aligned}$ & \multirow{4}{*}{$\begin{array}{l}0.006^{1} \\
\text { n.d. }{ }^{2}\end{array}$} \\
\hline $\begin{array}{l}13 \\
13\end{array}$ & $\begin{array}{l}\text { well no. } 1 \\
\text { well no. } 1\end{array}$ & $\begin{array}{l}0.45 \mu \mathrm{m} \\
0.05 \mu \mathrm{m}\end{array}$ & $\begin{array}{r}9.99 \\
12.82\end{array}$ & $\begin{array}{l}\text { n.d. } 2 \\
\text { n.d. } 2\end{array}$ & $\begin{array}{l}1.16 \\
0.93\end{array}$ & $\begin{array}{l}\text { n.d. } 2 \\
\text { n.d. } 2\end{array}$ & $\begin{array}{l}\text { n.d. } 2 \\
\text { n.d. } 2\end{array}$ & \\
\hline $\begin{array}{l}13 \\
13\end{array}$ & $\begin{array}{l}\text { well no. } 4 \\
\text { well no. } 4\end{array}$ & $\begin{array}{l}0.45 \mu \mathrm{m} \\
0.05 \mu \mathrm{m}\end{array}$ & $\begin{array}{l}8.04 \\
8.65\end{array}$ & $\begin{array}{l}\text { n.d. } 2 \\
\text { n.d. } 2\end{array}$ & $\begin{array}{l}0.57 \\
0.92\end{array}$ & $\begin{array}{l}\text { n.d. } 2 \\
\text { n.d. } 2\end{array}$ & $\begin{array}{l}\text { n.d. } 2 \\
\text { n.d. } 2\end{array}$ & \\
\hline $\begin{array}{l}13 \\
13\end{array}$ & $\begin{array}{l}\text { well no. } 3 \\
\text { well no. } 3\end{array}$ & $\begin{array}{l}0.45 \mu \mathrm{m} \\
0.05 \mu \mathrm{m}\end{array}$ & $\begin{array}{r}<0.128 \\
\text { n.d. } 2\end{array}$ & $\begin{array}{r}<4.982 \\
\text { n.d. } 2\end{array}$ & $\begin{array}{r}<0.044 \\
\text { n.d. } 2\end{array}$ & $\begin{array}{r}<0.032 \\
\text { n.d. }\end{array}$ & $\begin{array}{r}<0.029 \\
\text { n.d. } 2\end{array}$ & \\
\hline
\end{tabular}

\footnotetext{
1 counts per second and liter

2 n. d.: not detected, limit unknown

3 contamination can not be excluded
} 
$\mid-131$

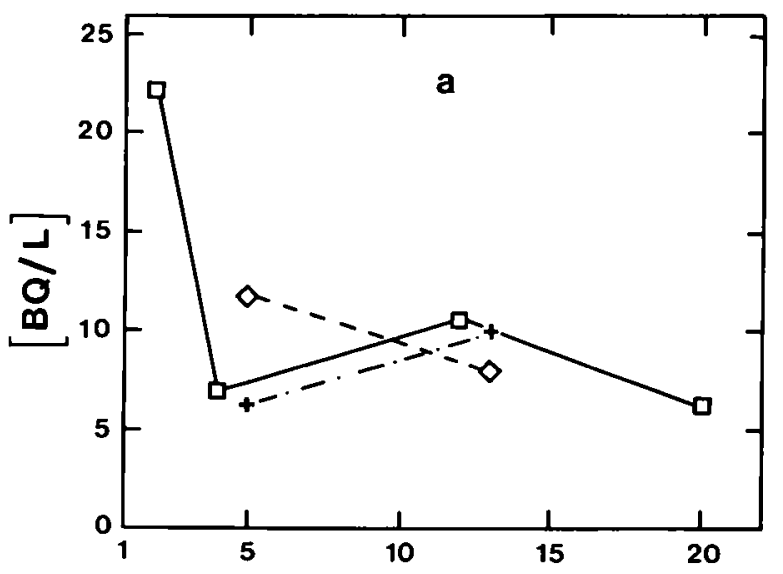

Ru - 103

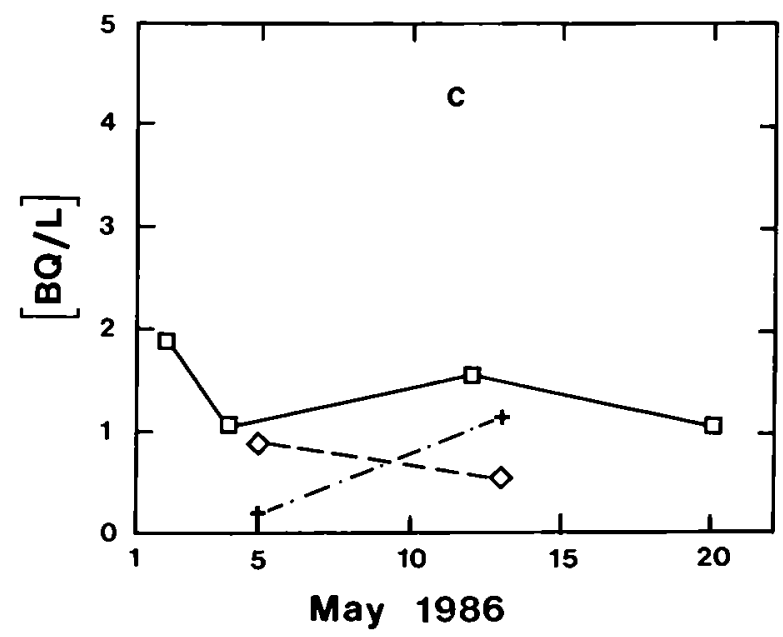

Te -132

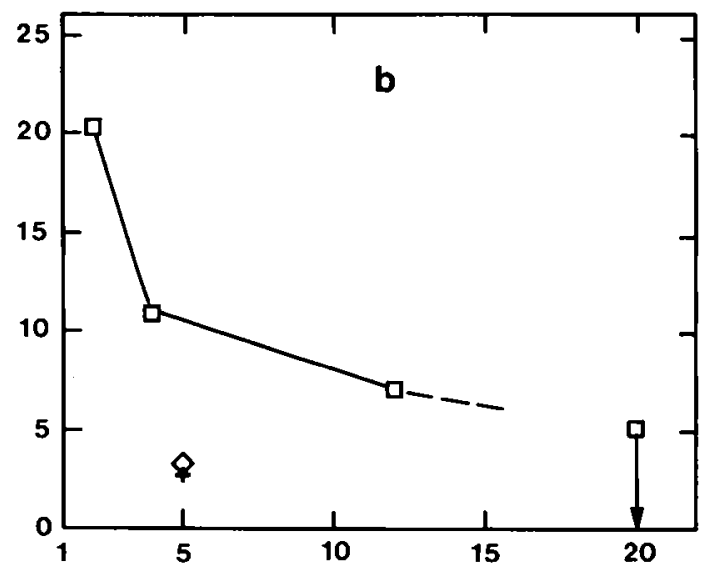

Cs $-137 / C s-134$

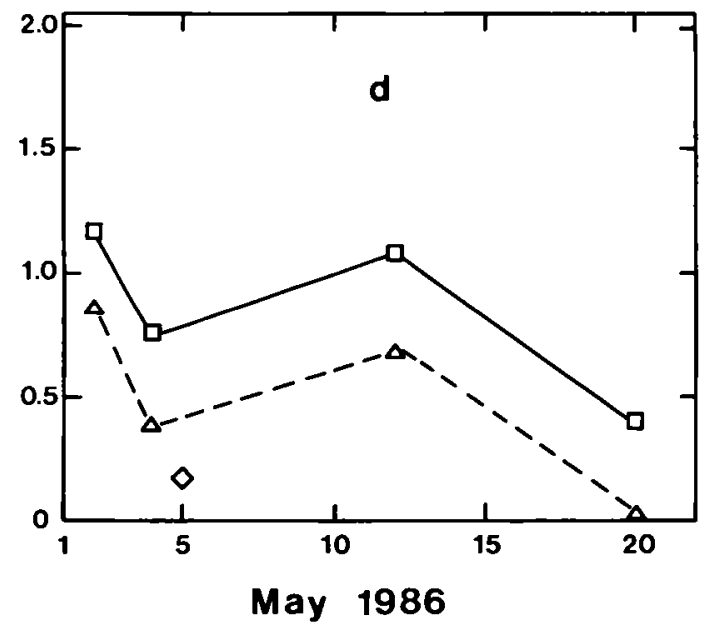

Fig. 2. Time dependent variation of the radioactivity in the filtered (with folded filters or $0.45 \mu \mathrm{m}$ filters) river water and groundwater. a - c: a river water, + well no. 1 , $\diamond$ well no. 4 , d: $\square$ river water Cs $-137, \Delta$ river water Cs -134 , $\diamond$ well no. 4 .

values given in Tables 1 and 2 are in the range of 10 to $50 \%(1 \sigma)$ depending on the activity of the different samples.

\section{Results and discussion}

The experiments were possible due to the fact that a well equipped experimental test field and the necessary sampling techniques were available when the Chernobyl fallout reached Switzerland. In addition the hydro-geology of the test field and the groundwater flow velocities had been sufficiently established $[13,14]$. Despite these facts there was too little time left for a very careful preparation of the experiments. Therefore, the results should be observed with some care, even if they are quantitative in general. Furthermore, it was rather unfortunate that we stopped sampling in the groundwater wells at a too early time and too close to the river. Continuing sampling at greater distances from the river might have led to further interesting results about the migration of radionuclides in this aquifer.
The results are presented in Tables 1 and 2 and Figures 2 and 3 . In the following sections a separate discussion for each radioelement is given.

\subsection{Iodine -131}

The activity of ${ }^{131} I$ in the filtered river water varied with time (Table 1, Fig. 2a). On May 2nd the activity was more than $22 \mathrm{~Bq} / 1$. It reached a minimum on May $4^{\text {th }}$ with $7 \mathrm{~Bq} / 1$, increased again to $10 \mathrm{~Bq} / 1$ (May $12^{\text {th }}$ ) and was sampled finally on May $20^{\text {th }}(7 \mathrm{~Bq} / 1)$. This variation of the activity with time might be due to rain on May $7^{\text {th }}$ and $11^{\text {th }}$ [16] that increased the input of contaminated water and/or to an additional later release of radioiodine from the damaged power plant. A similar variation of the ${ }^{131} \mathrm{I}$ activity was observed in the groundwater (Fig. 2a, Table 2): on May 5th the activity in well no. $1(6 \mathrm{~Bq} / 1)$, where the river water arrives with a delay of approximately one day, was about the same as in the $\operatorname{river}(7 \mathrm{~Bq} / \mathrm{l})$ one day before. On May $13^{\text {th }}$ the groundwater activity in the same well was higher $(10 \mathrm{~Bq} / 1)$ than on May $5^{\text {th }}$ 


\section{Water/particles}

Iodine-131

a)

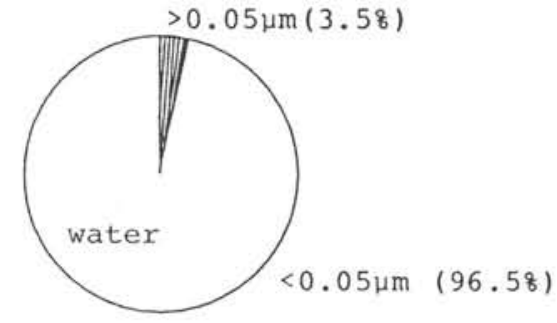

Tellurium-132

c)

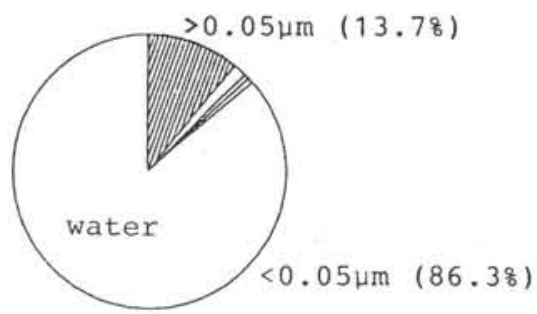

Ruthenium-103

e)

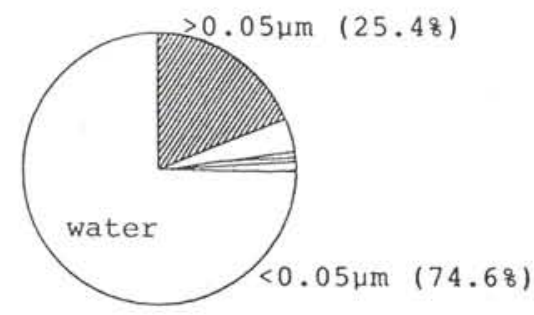

Cesium-137

g)

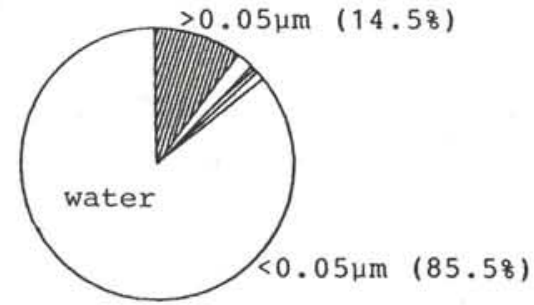

Particles

Iodine-131

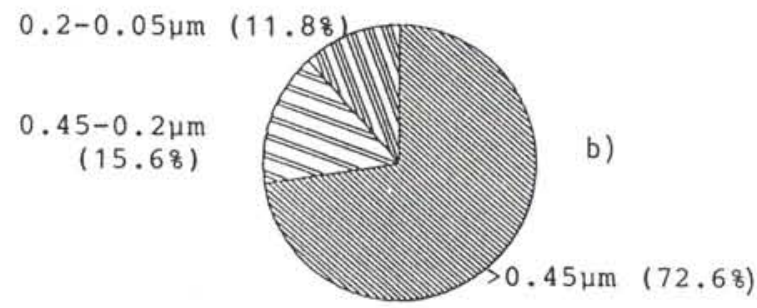

Tellurium-132

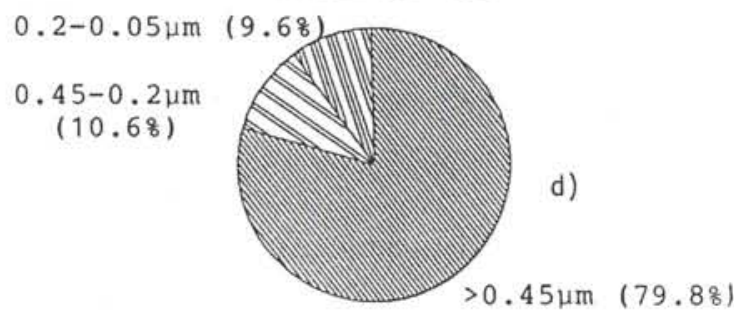

Ruthenium-103
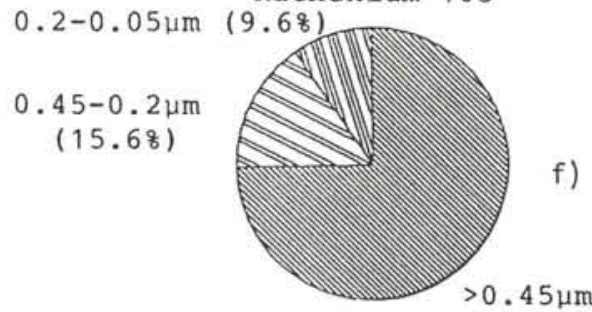

$(74.88)$

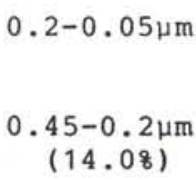

Cesium-137

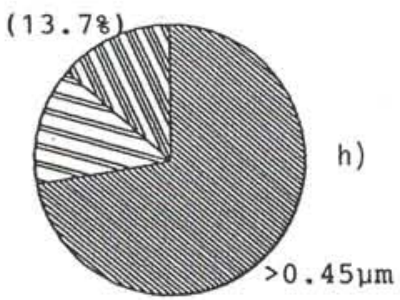

$(72.38)$

Fig. 3. Activity distribution in the river water from May $5^{\text {th }}$ between dissolved $(<0.05 \mu \mathrm{m})$ and particulate fraction $(>0.05 \mu \mathrm{m})$ and among the different size fractions of the particles $(0.05-0.20 \mu \mathrm{m}, 0.20-0.45 \mu \mathrm{m}$ and $>0.45 \mu \mathrm{m}$ ).

and again about equal to the activity $(11 \mathrm{~Bq} / \mathrm{l})$ in the river water one day before. This indicates an almost complete and unretarded infiltration of the dissolved $(<0.05 \mu \mathrm{m}){ }^{131} \mathrm{I}$ from the river into the groundwater stream. This behaviour is expected for an anion which is not sorbed by soil minerals. Due to anion exclusion it may move even faster than the water; however the groundwater flow velocity is not known well enough for an observation of this small effect. At a distance of $5 \mathrm{~m}$ from the river (well no. 4) we observed the same time dependent activity variation taking into account approximately two days for the water to flow from the river to well no. 4 , and assuming a linear increase of the activity in the river between May $4^{\text {th }}$ and $12^{\text {th }}$ as indicated by the solid line in Fig. 2a. The activity in the groundwater (well no.4) was slightly lower than in the river. This might be due to dilution with uncontaminated water from greater depth and/or to dispersion. In well no. 3 at a depth of $15 \mathrm{~m}$ 
no activity was observed (Table 2 ). Thus, the ${ }^{131}$ I activity at a distance of $5 \mathrm{~m}$ from the river also corresponded approximately to that of the river water.

Fig. 3a shows the distribution of ${ }^{131}$ I between particles $(>0.05 \mu \mathrm{m})$ and solution $(<0.05 \mu \mathrm{m})$ in the river. More than $95 \%$ of the activity was found in solution either as soluble iodide or possibly bound to particles of diameter $<0.05 \mu \mathrm{m}$. Ninety $\%$ of the ${ }^{131}$ I was present as iodide, only $10 \%$ could be precipitated as lead iodate. This result is in agreement with recent data of PALMER et al. [17] who investigated the disproportionation of iodine in an aqueous medium. The chemical form of the atmospheric ${ }^{131}$ I fallout from Chernobyl cannot be deduced from our data and the speciation during emission and imission is still disputed. Only $3.5 \%$ of the total ${ }^{131}$ I activity was found on particles $(>0.05 \mu \mathrm{m})$, the main activity $(73 \%)$ being in the fraction $>0.45 \mu \mathrm{m}$ (Fig. $3 \mathrm{~b}$ ). The rest of the particulate activity was almost equally distributed between the two smaller sizes of $0.20 \mu \mathrm{m}-0.45 \mu \mathrm{m}(15 \%)$ and $0.05 \mu \mathrm{m}-0.20 \mu \mathrm{m}(12 \%)$. This result contrasts with measurements of the distribution of ${ }^{131}$ I among atmospheric particles from Chernobyl fallout $[18,19]$. Here, the highest activity of ${ }^{131} \mathrm{I}$ was found in the particle fraction $<0.47 \mu \mathrm{m}$. This means that ${ }^{131}$ I was at least partly redistributed after entering into surface waters. In the particulate fraction of the groundwater only a very small ${ }^{131}$ I activity was detected $(\ll 1 \%)$ indicating that ${ }^{131}$ I infiltrated predominantly as soluble iodide from the river into the groundwater and that particulate or colloidal transport is a very minor process for this nuclide.

\subsection{Tellurium-1 32}

The activity of ${ }^{132} \mathrm{Te}$ amounted to $20 \mathrm{~Bq} / 1$ on May $2^{\text {nd }}$ in the filtered (folded filters) river water (Fig. 2b). It decreased to $7 \mathrm{~Bq} / 1$ on May $12^{\text {th }}$ without exhibiting the minimum activity around May $4^{\text {th }}$ which was found for the other radionuclides. On May $20^{\text {th }}$ the activity was lower than the detection limit of $5 \mathrm{~Bq} / 1$. On May $5^{\text {th }}$, the activity level in groundwater well no. 1 was about $30 \%$ of that in the river, while well no. 4 had only $20 \%$ of the activity in the river. No activity was measured on May $13^{\text {th }}$ in the groundwater (detection limit: $5 \mathrm{~Bq} / 1$, well no. 3). These results show that ${ }^{132} \mathrm{Te}$ infiltrated only partly from the river into the groundwater, indicating sorption and retardation by the aquifer material. Fig. 3c demonstrates that the ${ }^{132} \mathrm{Te}$ activity is mainly transported in dissolved form $(<0.05 \mu \mathrm{m})$. Only $14 \%$ of the activity was detected on particles $>0.05 \mu \mathrm{m}$. The activity distribution among the particle size fractions is shown in Fig. 3d. The fraction $>0.45 \mu \mathrm{m}$ contained about $80 \%$ of the particulate activity, whereas the rest of the activity was distributed equally among the two smaller fractions $(0.20-0.45 \mu \mathrm{m}$ and $0.05-0.20 \mu \mathrm{m})$. This activity distribution on particles is in line with that in atmospheric fallout from Chernobyl [18, 19].

\subsection{Ruthenium-103}

The activity pattern of ${ }^{103} \mathrm{Ru}$ in the filtered river water (folded filters, Fig. 2c) was similar to that of ${ }^{131}$ I with a minimum activity on May $4^{\text {th }}$, but the values varied only between 1 and $2 \mathrm{~Bq} / 1$ during the observation period (Table 1). Twenty \% of the activity of the river water was found in well no. 1 on May $5^{\text {th }}$, and on May $13^{\text {th }}$ more than $70 \%$, while $60 \%$ was found in well no. 4 on May $5^{\text {th }}$ and $46 \%$ on May $13^{\text {th }}$ (Fig. $2 \mathrm{c}$ and Tables 1 and 2). However, in the $0.05 \mu \mathrm{m}$-filtrated river water and in the equally filtrated groundwater in wells no. 1 and no. 4 comparable activities of about $1 \mathrm{~Bq} / \mathrm{l}$ were found (Tables 1 and 2), indicating a practically complete infiltration of soluble ${ }^{103} \mathrm{Ru}$ without sorption and retardation. Some of the activity values for the $0.05 \mu \mathrm{m}$-filtered groundwater samples were higher than the values of the $0.45 \mu \mathrm{m}$ filtered samples. This may be due to inaccuracy during measurement or due to sorption effects on the filters made of different materials $(0.45 \mu \mathrm{m}$ : cellulose acetate; smaller sizes: cellulose nitrate). The soluble ${ }^{103} \mathrm{Ru}$ is probably present as an anion or a neutral complex, both showing only a slight affinity to the aquifer material. The fraction $>0.05 \mu \mathrm{m}$ of the ruthenium activity of the river water sample of May $5^{\text {th }}$ amounted to $>25 \%$ of the total activity (Fig. 3e). The main part of this activity was found on particles $>0.45 \mu \mathrm{m}(75 \%)$, and the rest of the activity was about equally distributed between the two smaller fractions $0.20-0.45 \mu \mathrm{m}(15 \%)$ and $0.05-0.20$ $\mu \mathrm{m}(10 \%$ Fig. $3 \mathrm{f})$. This activity distribution among particulate matter is again similar to that found in atmospheric fallout from Chernobyl [18, 19]. Atmospheric

${ }^{103} \mathrm{Ru}$ fallout might, thus, not have changed its size distribution upon entering the aqueous environment. No ${ }^{103} \mathrm{Ru}$ activity was found in the deep groundwater well no. 3 .

\subsection{Cesium -134 , Cesium-137}

For both, ${ }^{134} \mathrm{Cs}$ and ${ }^{137} \mathrm{Cs}$, the activity of the river water varied during the period of investigation in a similar way (Fig. 2d) as the activity of ${ }^{131} \mathrm{I}$ and of ${ }^{103} \mathrm{Ru}$. The activity was minimal on May $4^{\text {th }}\left({ }^{134} \mathrm{Cs}: 0.4 \mathrm{~Bq} / 1 ;{ }^{137} \mathrm{Cs}\right.$ : $0.8 \mathrm{~Bq} / 1)$. Only ${ }^{137} \mathrm{Cs}$ was measured on May $20^{\text {th }}$, because ${ }^{134} \mathrm{Cs}$ was already below the detection limit of $0.06 \mathrm{~Bq} / 1$. The ratio of ${ }^{137} \mathrm{Cs} /{ }^{134} \mathrm{Cs}$ was between 1 and 2 for all measurements. With the exception of one sample out of five there was no Cs-activity measured in the groundwater (Table 2), indicating a complete sorption of cesium by the aquifer material. The activity in well no. 4 on May $5^{\text {th }}$ was probably due to contamination introduced during sampling. The sorption of cesium by different soil minerals is widely discussed in the literature [20-25]. Cesium is strongly sorbed by clay minerals that are able to exchange it against other ions, mainly $\mathrm{K}^{+}$.

The ${ }^{137} \mathrm{Cs}$ activity of the particles $>0.05 \mu \mathrm{m}$ of the river water on May $5^{\text {th }}$ amounted to about $15 \%$ (Fig. $3 \mathrm{~g}$ ), i. e. most of the Cs was found in the fraction passing the 
$0.05 \mu \mathrm{m}$ filter. As for ${ }^{132} \mathrm{Te}$ and ${ }^{103} \mathrm{Ru}$ the particulate activity of ${ }^{137} \mathrm{Cs}$ was largest in the $>0.45 \mu \mathrm{m}$ size fraction (Fig. 3h). Also for this nuclide the distribution is similar to atmospheric fallout from Chernobyl. No size distribution can be given for ${ }^{134} \mathrm{Cs}$ due to lack of data from the $0.05 \mu \mathrm{m}$-filtered river water.

\subsection{Technetium $-99 \mathrm{~m}$}

Counting rates for ${ }^{99 \mathrm{~m}} \mathrm{Tc}$ are listed in Tables 1 and 2 . There was no calibration performed for this nuclide. $99 \mathrm{~m}$ Tc was measured only twice, once in the river on May 2nd (filtered water: $0.02 \mathrm{cps} / 1$, particulate fraction $0.005 \mathrm{cps} / 1)$ and once in the groundwater on May $5^{\text {th }}$ (well no. 4: $0.01 \mathrm{cps} / 1$ ). ${ }^{99 \mathrm{~m}} \mathrm{Tc}$ infiltrated probably as anionic pertechnetate. In this form it was, like ${ }^{131} \mathrm{I}$, only slightly sorbed by the aquifer material.

\subsection{General discussion}

Based on the infiltration behaviour of the measured radionuclides we suggest that they were predominately present in the following speciation: ${ }^{131} \mathrm{I}$ as iodide, ${ }^{134} \mathrm{Cs}$ and ${ }^{137} \mathrm{Cs}$ as $\mathrm{Cs}^{+},{ }^{132} \mathrm{Te},{ }^{103} \mathrm{Ru}$ and ${ }^{99 \mathrm{~m}} \mathrm{Tc}$ presumably as anionic or neutral complexes. Under the slightly alcaline conditions in the river and groundwater ( $\mathrm{pH} \mathrm{7.5-8)}$ tellurates should be stable. Anions and neutral complexes are not or only slightly sorbed by soil minerals. $\mathrm{Cs}^{+}$, on the other hand, is very strongly sorbed by the clay minerals illite and chlorite $[23,25]$, which are found in sufficient amounts in the quarternary deposits of the Swiss plains.

Negligible activities were found on particles $(>0.05$ $\mu \mathrm{m})$ in the groundwater samples. Particulate transport of the radionuclides can, therefore, practically be excluded; certainly it is not a process of importance in an aquifer of this composition.

The activities of all radionuclides measured in this work were always below Swiss drinking water limits [26]. It takes about two months time for the infiltrating river water to reach the drinking water sampling station [27]. Therefore, the activity from the Chernobyl accident did never endanger the drinking water at Glattfelden.

\section{Conclusions}

- In the River Glatt more than $75 \%$ of the activity of all radionuclides was found in the filtered water $(<0.05 \mu \mathrm{m})$ The radionuclides in this fraction were either dissolved or sorbed to particles with sizes $<0.05 \mu \mathrm{m}$.

- $70 \%$ of the particulate radioactivity was found in the size fraction $>0.45 \mu \mathrm{m}$. The rest of the activity was about equally distributed between the two smaller particle fractions.
- For ${ }^{132} \mathrm{Te},{ }^{103} \mathrm{Ru}$ and ${ }^{137} \mathrm{Cs}$ the activity distribution among particles was similar to the atmospheric fallout from Chernobyl, in contrast to ${ }^{131} \mathrm{I}$ where the activity distribution in the aqueous environment had shifted to larger size fractions compared to the atmospheric distribution.

- With the exception of $\mathrm{Cs}$ the measured radionuclides were probably present to a large extent as anionic and/or neutral species and infiltrated in these forms practically unretarded into the groundwater.

- Cesium was strongly sorbed in the aquifer material. Therefore, its infiltration is strongly retarded.

- Infiltration of particulate radioactivity with sizes $>0.05 \mu \mathrm{m}$ from the river into the groundwater can practically be excluded.

- No radioactivity was measured in the groundwater of greater depth $(15 \mathrm{~m})$.

- A hazardous contamination by the Chernobyl fallout of the drinking water recovered from this aquifer can certainly be excluded.

\section{Acknowledgments}

The authors thank M. KOHLER, M. KUSLYS and C. LIENERT for their help during sample collection and measurement, E. ROSSLER for the preparation of standard solutions and R. WELCH and D. ZIMMERMANN for valuable discussions. The work was partly supported by the Swiss National Science Foundation.

\section{References}

1. von G UNTEN, H. R., KULL, T. P.: Water, Air, Soil Pollut. 29, 333 (1986).

2. FÖRSTNER, U., MULLER, G.: GWF-Wasser/Abwasser 116 (2), 74 (1975).

3. REICHERT, J., HABERER, K., NORMANN, S.: Vom Wasser 39, 137 (1972).

4. SCHÖTTLER, U.: Z. Wasser, Abwasser Forsch. 9 (3), 88 (1976).

5. JAMES, B. R., BARTLETT, R. J.: J. Environ. Qual. 12 (2), 169 (1983).

6. ROBERT, P. V., SCHREINER, J., HOPKINS, G. D.: Water Res. 16, 1025 (1982).

7. SCHWARZENBACH, R. P., GIGER, W., HOEHN, E., SCHNEIDER, J. K.: Environ. Sci. Technol. 17, 472 (1983).

8. FÖRSTNER, U., SELlHORN, C.: Vom Wasser 67 (1986), in press.

9. BART, G., VON GUNTEN, H. R.: Schweiz. Z. Hydrol. 39 (2), 277 (1977).

10. FÖRSTNER, U., WITTMANN, G. T. W.: Metal Pollution in the Aquatic Environment, 2nd ed., Springer Verlag, Berlin/ Heidelberg/New York (1981).

11. LAXEN, D. P. H., DAVISON, W., WOOF, C.: Geochim. Cosmochim. Acta 48, 2107 (1984).

12. FÖRSTNER, U., CALMANO, W., SCHOER, J.: Vom Wasser 64, 1 (1985)

13. HOEHN, E., ZOBRIST, J., SCHWARZENBACH, R. P.: Gas-Wasser-Abwasser 63 (8), 401 (1983). 
14. HOEHN, E.: private communication.

15. CURRIE, L. A.: Anal. Chem. 40, 586 (1968).

16. Neue Zürcher Zeitung 129, 8 (1986)

17. PALMER, D. A., RAMETTE, R. W., MESMER, R. E.: J. Nucl. Mater. 1 30, 280 (1985).

18. NYFFE LER, U., GÄLLI, B., BÜR KI, P., KRÄHENBÜHL, U.: Proc. Symposium "Radioakt ivitätsmessungen in der Schweiz nach Tschernobyl und ihre wissenschaftliche Interpretation", Bern (1986), p. 121.

19. JOST, D. T., GÄGGELER, H. W., BALTENSBERGER, U.: Nature 324, 22 (1986).

20. SCHULZ, R. K., OVERSTREET, R., BARSHAD, I.: Soil Sci. 89, 16 (1960).
21. TORSTEnFElT, B., ANDERSON, K., AlLARD, B.: Chem. Geol. 36, 123 (1981).

22. GRUTTER, A., RÖSSLER, E.: TM-44-83-08, EIR, unpublished (1983).

23. GRUTTER, A., VON GUNTEN, H. R., RÖSSLER, E.: Clays Clay Miner. 34 (6), 677 (1986).

24. KOHLER, M.: PhD-Thesis, Universität Bern (1987).

25. SAWHNEY, B. L.: Clays Clay Miner. 20, 93 (1972).

26. Verordnung über den Strahlenschutz, Eidg. Drucksachen- und Materialzentrale, Bern (1976).

27. SANTSCHI, P. H., FARRENKOTHEN, K., LUCK, A., HUPPI, H. J., WERTH, E., HOEHN, E.: EAWAG-News $16 / 17,7$ (1984). 